\title{
Does Liquidity Influence Profitability in Islamic Banks of Bahrain: An Empirical Study?
}

\author{
Hussein Khasharmeh ${ }^{1}$ \\ ${ }^{1}$ Accounting and Finance Department, Applied Science University, Kingdom of Bahrain \\ Correspondence: Hussein Khasharmeh, Associate Professor, Accounting and Finance Department, Applied Science \\ University, Kingdom of Bahrain.
}

Received: March 9, 2018

Accepted: April 17, 2018

Online Published: April 22, 2018

doi:10.5430/ijfr.v9n2p236

URL: https://doi.org/10.5430/ijfr.v9n2p236

\begin{abstract}
This study examines the impact of liquidity on Islamic banks' profitability during the years from 2010 to 2015 . The study extracted its data from the annual reports of six Islamic banks in Bahrain that have been in operations on or before 2010 to 2015 . The liquidity model is built from four liquidity variables namely cash \& due from banks to total assets (CDTA), cash \& due from banks to total deposits (CDTD), investment to total assets (INVSTA) and investment to total deposits (INVSTD). According to adjusted $\mathrm{R}$ squares profitability variables return on assets (ROA), return on equity (ROE) and return on deposits (ROD) are respectively $16.2 \%, 3.1 \%$ and $21.3 \%$ dependent on liquidity variables.

The results of the study show that CDTD and INVSTD are correlated positively with ROE. In addition, CDTD, INVSTA indicate a negative correlation with ROE. Thus, only INVSTA and INVSTD found to be significant with ROE at 0.05 significant level. Durbin-Watson test shows that the residuals are uncorrelated since its value is approximately very close to 2 . However, according to the P-value, the overall liquidity model (Model 2) is not significantly related with ROE. Thus, the null hypothesis (H0) is accepted and the alternative hypothesis is rejected for the ROE. Furthermore, the results in the table show that CDTA and INVSTD are positively correlated with ROD, and negatively with CDTA and INVSTA, and CDTA is the only insignificant variable. CDTD is significantly related with ROD at $10 \%$. Durbin-Watson test shows that the residuals are positive auto - correlated since its value is approximately very close to 1 . However, according to the P-value, the overall liquidity model (Model 3), is significantly related with ROD at $1 \%$ level.
\end{abstract}

The researcher recommended for further studies to add more liquidity variables to the model so as to enhance and enrich Islamic banks outlook.

Keywords: financial ratios, Bahrain, Islamic banks, profitability, liquidity, performance

\section{Introduction}

Profitability and liquidity are the main variables used by Islamic banks to gauge its performance. The ability of the bank to achieve profits based on the revenues earned during the period.

Liquidity measures the ability of the bank to meet its obligations on due date and this feature will determine the extent of liquidity risk accompanied with its operation. There is a need to gauge Islamic banks performance among countries and becomes worth demanding.

Zolkifli et al., (2015, p.95) indicated "Liquidity becomes a major risk in banking and the liquidity management should give priority for bank management and regulators to make this issue. With the existence of liquidity risk, banks need to be cautious with the cash flow that happens to bank profits can be maintained without being affected by liquidity risk".

"Perhaps, the most significant risks of an Islamic bank is to build a sound liquidity management" (Rasul, 2013, p.24). It seems that Islamic bank has been demanded by large segment of people in Bahrain because it is established according to Sharia principles and based on interest-free banking services. 
According to Rusal, (2013, p.24) "Excess liquidity generated by Islamic banks cannot be easily shifted to conventional banks as the Islamic banks do not accept interest; while there is opportunity for exchange of excess funds among Islamic banks on a Mudarabah / Musharakeh basis".

Khan et al., (2015, p. 76) pointed out that "The Islamic banking is a system that is in agreement with spirit and value system, and fully governed by the Sharia principles. Islamic banks prohibit the interest based transactions as well as disallow unsocial and unethical endeavors. The Islamic banking model aims at gauging and achieving prosperous economy adjacent to socio benefits. Sharia strictly forbids the special receipt or payment (Riba) for money lent or borrowed".

This study conducted a comparative analysis about the impact of liquidity upon profitability in Bahrain and Kuwait. "Bahrain as the Gulf's financial capital for more than 40 years, has led the Middle East in a range of sectors - from Banking to asset management, to Islamic finance" (Suresh and Bardastani, 2016, p.24) and same for the Kuwait. This comparison is "quite rational and significant, because it will expatiate greatly, to mitigate the knowledge gap prevailing in literature and it will provide the policy makers a comprehensive analysis of profitability and liquidity of Islamic banks". (Khan et al, 2015, p.77).

Islamic Banking “form the biggest part of Bahrain's and UAE's financial services sector are playing major role in mobilization of savings, augmenting capital formation, facilitating investments in all sectors of Bahrain and Kuwait economy and promoting economic development in these countries" ( Suresh and Bandastani, 2016, p.24).

Suresh and Bardastani (2016, p.25) added that "Islamic banks offer a variety of banking services such as foreign exchanging business, money transfers, documentary trade finance, portfolio management and underwriting of capital Market issues"

"The actual role of Islamic banks inherits in promoting and empowering the banking services and products based on Islamic principles" (Rasul, 2013, p. 23). "The main principles of Islamic banking comprise of prohibition of interest in all forms of transaction, and undertaking business and trade activities on the basis of fair and legitimate profit" (Haron and Shanmugan, 1997, cited in Rasul, 2013, p.23). However, profit free of risks or hazards in the economic understandings is forbidden under Islamic principles.

The people in Bahrain are highly demanded Sharia approved banking system. Thus, the question arises is: Does liquidity influence profitability for overall Islamic bank industry in Bahrain.

Suresh and Bardastani, (2016, p.26) pointed out that "Since growth, efficiency and competitive environment are quintessential for the economic stability and development, it is important to analyze the performance and examine the impact of liquidity upon the performance in Bahrain, and thus the current study is expected to fill the gap in this issue".

Bahrain has been chosen for this study because Islamic banks play a crucial role in this country as a Muslim country. Also, the choice is based on the fact that the banking system in Bahrain is running using Islamic banking system. "As a largest consumer bank in Bahrain, Islamic banking operates in a very good perspective in the Islamic banking industry. This makes Bahrain famous for its Islamic banking system trusted by society. Bahrain is also among the GCC countries and the most actively promoting Islamic finance and makes it survive in the banking industry despite the global financial crisis". (Zolkifi et al., 2015, p.96).

For the best knowledge of researchers, this study is the first that attempts to determine the impact of liquidity upon profitability in Islamic banks in the Bahrain and the UAE.

The main objective of the study is to examine the impacts of liquidity upon profitability in Islamic banks in Bahrain. The study contributes in narrowing the gap identified in the literature regarding this issue. The objectives of the study can be summarized as follows:

1. To focus on the attributes of Islamic banks.

2. Analyze the performance of Islamic banks.

3. Examine the impact of liquidity upon profitability in Islamic banks.

4. Come up with some findings and recommendations that may add value to the literature review.

In order to achieve such objectives, the following questions need to be answered:

1. Is there any impact of liquidity upon profitability of Islamic banks in Bahrain?

2. What indicators used to measure liquidity and profitability in Islamic banks? 
This study organized as follows: Section 2 presents the theoretical framework. Section 3 provides the literature review, section 4 provides for the methodology, section 5 presents the results and analysis. Section 6 presents the conclusions and recommendations.

\section{Theoretical Framework}

The Islamic financial institutions have grown from about $\$ 150$ billion in the mid-1990's to around $\$ 700$ billion in 2007 (HM Treasury, 2007, cited in Babatunde and Olaitan, 2013, p. 30). "Today, Islamic banks are operating in more than sixty countries with assets base on more than $\$ 160$ billion and a marked annual growth rate of $10 \%-15 \%$. In the credit market, market share of Islamic banks in Muslim countries has risen from 2\% in the late 1970s to about $15 \%$ to day" (Rajesh et al., 2000, cited in Usman and Khan, 2012, p. 253).

(Ryu et al., 2012, cited in Babatunde and Olaitan, 2013, p. 30) demonstrated that "The Islamic banking system which is based on the tents of Islamic law (Sharia) prescribes equity participation in investment. A distinctive feature of Islamic finance is that it does not allow the creation of debt through direct lending and borrowing of money or other financial assets. Debts can only be created through the sale or lease of real assets through lease based financing schemes".

According to Jill et al., (2009, cited in Babatunde and Olaitan, 2013, p. 30), "growth in the Islamic banking sector has been ignited by the introduction of innovative products aimed at satisfying its customers". Islamic banks may enhance the economic value chain by getting involved in the procurement and management of capital assets and commodities" (El and Zeinab, 2005, cited in Babatunde and Olaitan, 2013, p. 31).

Banks today are under great pressure to perform - to meet the objectives of their stockholders, employees, depositors and borrowing customers, while somehow keeping government regulators satisfied that the bank's polices, Loans and investments are sound (Rose, 2004-2005, cited in Rasul, 2013, p.24).

According to Islamic Shariah, profit is simply a compensation of bearing risk. On the other hand, "liquidity implies availability of cash that how bank rapidly may convert its assets into cash to meet the need of short term. It is considered as a life of the banks. Higher amount of the liquid assets reflect the greater liquidity of the firm" (AKhter, et al. 2011, cited in Rasul, 2013, p.25).

(Khan and Ahmed, 2001, cited in Rasul, 2013, p.25) pointed out "the essence of liquidity management problem arises from the fact that there is trade-off between liquidity and profitability and mismatch between demand and supply". Haron (2004 cited in Rasul, 2013, p.25) pointed out "liquidity, funds invested in Islamic securities, total expenditures and the percentage of the profit-sharing ratio between the bank and the borrower of funds are highly correlated with the level of total income received by the Islamic banks. He also added that other determinates such as funds deposited into current accounts, total capital and reserves, the percentage of profit sharing between bank and depositors, as well as money supply also play a major role in influencing the profitability of Islamic banks".

Ratio analysis used to evaluate and interpret financial ratios to assess Islamic bank performance. Financial ratios are used as indicators of the bank's financial performance.

"The growth of Islamic banking has been increasing ever since, not only in terms of number of countries it is operating in but also in terms of areas of finance it has ventures (EL Gamal, 2006, cited in Rana et al., 2016, p. 322). "Ratio analysis is a useful tool for business owner as it measures the health and performance of the business in terms of profitability, asset utilization, liquidity, leverage, or market valuation to diagnose potential problems and to see how well it is doing over time" (Najjar, 2013 cited in Milhem and Istaiteyeh 2015, p.31).

According to (Chapra, 1996, cited in Usman and Khan, 2012, p. 254) 'Islamic banking is the system of banking consistent with principles of Islamic law (Sharia) and guided by Islamic economics. Islamic economics is referred to that body of knowledge which helps to realize human well-being through an allocation and distribution of scarce resources that is in conformity with Islamic teachings". Islamic banks are based on an interest free principle and principle of profit and loss (PLS) sharing in performing their businesses as intermediaries. Islamic PLS principle creates the relationship of financial trust and partnership between borrowers, leader, and intermediary (Yundistira, 2003, cited in Usman and Khan, 2012, p. 254).

"Islamic banks are based on four rules that govern investment behavior.

a. The absence of interest - based (RIBA) transactions;

b. The avoidance of economic activities involving hypothesis;

c. The introduction of an Islamic tax, ZAKAT. 
d. The discouragement of the production of goods and services which is prohibited (HARAM) in Islam. (Suleiman, 2001 cited in Usman and Khan, 2012, p. 254).

According to (Islam, 2008, cited in Rasul, 2013, p. 27) "Liquidity is of vital importance to the daily operations of a bank. Maintenance of a sound Liquidity position of a bank is necessary to protect the bank against uncertainties of its business. A tradeoff between risk and return can minimize the conflict between liquidity versus profitability of a bank".

(SBP, cited in Rana et al., 2016, p. 322) pointed out that "Islamic banking, the more general term is expected not only to avoid interest based transactions, prohibited in the Islamic Sharia, but also to avoid unethical practices and participate actively in achieving the goals and objectives of an Islamic economy". According to Rana et al., 2016, p. 322) "Islamic banking is the system of banking consistent with principles of Islamic Law (sharia) and guided by Islamic economics". They added, "Two basic principles behind Islamic banking are the sharing of profit and loss and, significantly, the prohibition of Usury, the collection and payment of interests, also commonly called Riba in Islamic discourse".

\section{Literature Review}

Many authors have been studied the topic of Islamic financial institutions. (Samad, 2004, cited in Rasul, 2013, p.25) pointed out that "Return on assets (ROA) is a good sign to determine banks financial performance and supervisory efficiency. The higher the ROA, the higher is the financial performance or profitability of the banks" (Akhter et al., 2011 cited in Rasul, 2013, p.25) indicated that "Return on equity measures the rate of return on the basis of capital". This ratio identifies how bank can perform profit with funds invested by shareholders. The higher the funds mean the higher of financial performance.

According to (Rosly and Baker, 2003, citer in Rasul, 2013, p. 26) "ROA and ROE are also indicators for managerial efficiency". (Ika and Abdullah, 2011, cited in Rasul, 2013, p. 26), return on deposits indicates the effectiveness of bank in converting deposit into net earnings.

Loans - assets ratio measures the percentage of assets tied up to loans. The higher the ratio, the less liquid the bank will be (Samad, 2004, cited in Rasul, 2013, p. 26.).

Rana et al. (2016, p. 318) conducted a study "that analyses the performance of Islamic banks versus conventional banks in Bangladesh over the period of 2013-2014. This study aimed to compare the profitability and liquidity of Islamic banks with conventional banks in Bangladesh". The study revealed that Islamic banks in Bangladesh show higher profitability than conventional banks. "Performance of interest-free Islamic banks in business development, profitability, liquidity and solvency is superior to that of interest-based conventional bank That is comparatively Islamic banks are superior in financial performance to that of interest-based conventional banks" Rana et al., 2016, p. 318.

Suresh C and Bardastani M. (2016, p. 23) conducted a study that "evaluates and compares the performance of retail conventional and Islamic banks in Kingdom of Bahrain for the period 2007-14". The results of the study show that "not only a better performance by Islamic banks in the inter-performance analysis; it has also identified huge variations in the performance of the banks within the sub-parameters under study". Thus, " the conclusion drawn from the study is that Islamic banks secured top position compared to conventional banks despite their business being constrained by the Sharia rules which prohibits them to undertake all profit making activities" (Suresh and Bardastani, 2016, p. 24).

Ben Khediria et al., (2015, cited in Milhem and Istaiteyeh 2015, p.29) revealed that Islamic banks are on average more profitable, more liquid, better capitalized, and lower credit risk than conventional banks. Islamic banks have higher growth in equity, deposits, investment and total assets, better assets quality and capital adequacy, better credit performance, less risk due to excess liquidity and greater investment in government securities (Abdul-Majid et al., 2011, cited in Milhem and Istaiteyeh 2015, p.29).

Khan et al., (2015). aimed in their study at "evaluating and comparatively analyzing the financial performance of all full-fledged Islamic banks operating in Pakistan and five Islamic banks from Malaysia conveniently chosen, subject to profitability and liquidity (Khan et al., 2015, p. 75). The results revealed that "Malaysia Islamic banks are more profitable, liquid and well ahead to Pakistan Islamic banks in profit margin, profit to expense earning per share, cash ratio and loan to deposit ratio" (Khan et al., 2015, p.b75).

Milhem et al. (2015) in their study aimed to explain the performance of both Islamic and conventional banks in Jordan for the period of 2009-1013. The study used financial ratio analysis to measure the profitability, liquidity, risk 
and solvency and efficiency. The results revealed that " there are differences in performance between Islamic and conventional banks in Jordan during the study period in terms Islamic banks are less profitable, more liquid, less risky, and less efficient comparing to conventional banks" (Milhem and Istaiteyeh, 2015, p.27).

Zolkifli et al. (2015) examined the determinants of liquidity risk and performance in both conventional and Islamic banks. Panel data analysis was used in the study. The study found that capitalization is the most significant determinant factor of liquidity risk. Also, the study revealed that capitalization has a strong relationship with performance. Based on their findings, the problem of liquidity risk related to regulatory requirements will decrease and this will lead banks to increase their profitability and improve their financial performance".

Ibrahim et al. (2014, cited in Rana et al., 2016, p. 319) conducted a study to evaluate the performance of Islamic banks listed in Dhaka Stock Exchange and Chittagong Stock Exchange. The study concluded that some banks are better than others using different ratios. The authors indicated that Islamic banks in Bangladesh have future bight.

Islam et al. (2014 cited in Rana et al., 2016, p. 319) examined the profitability of both Islamic banks and conventional banks in Bangladesh. The study revealed that conventional banks are more profitable.

Babatunde and Olaitan (2013) examined in their study the efficiency of performance in both Islamic and conventional banks in the UK for the period from 2007-2011. The results found few significant differences in the areas of liquidity, profitability, risk and solvency and efficiency. They also found that Islamic banks are less subject to liquidity risk and more cost- effective. The study suggested the broadening of Islamic banking finance management skills.

Paul et al. (2013) conducted a study that aimed to evaluate the profitability and liquidity of two groups of banks, i. e, Islamic banks and conventional banks for the period of 2008 to 2012. The researchers used different financial ratios, for both profitability and liquidity. The study revealed that Islamic banks are less preferable than conventional in years 2008 and 2009 in all profitability indicators. The study also found that there is no significant difference in liquidity between the two groups of banks. Moreover, the study revealed that Islamic banks are less profitable than conventional during the whole period under study.

Rasul (2013) conducted a study investigated how liquidity influences profitability of Islamic banks in Bangladesh. The result of the study concluded that cash and due from banks to total assets ratio is significant with all profitability variables used in the study, whereas cash and due from banks is found significant with all profitability variables used by the study except ROE. Also, investment to total assets and investment to total deposits are both recognized significant with all of return on assets (ROA), return on Equity (ROE) and return of deposits (ROD) variables.

Ernst and Young, (2012, cited in Khan et al , 2015, p.79) demonstrated that "industry is in need of transforming regulatory framework, risk and retail banking, so, the operations can be optimized and integrated with technology and mitigation of risk may be made possible".

A study conducted by Usman A. and Khan (2012) aimed to examine the financial performance of both Islamic and conventional banks in Pakistan. The results of the study revealed that Islamic banks are superior in growth rate and profitability over conventional banks. Also, the results show that Islamic banks have higher liquidity rate over conventional banks.

Akhtar et al. (2011) "found positive but significant relationship of size of the bank and net - working capital to net assets with liquidity risk in Islamic banks". Also they found that return on assets (ROE) is positive and significant with liquidity risk at $\mathrm{p}=0.1$.

(Khrawish, et al. 2011, cited un Rasul 2013, pp. 26-27) pointed out that "there are significant positive relationship between ROA and provision for Credit Facilities + Interest in Suspense/Credit facilities, Total Equity/Total Assets, and Total Income/Total Assets of the Islamic banking, and there are significant and negative relationship between ROA and the bank size, Total liabilities/Total assets, Annual Growth Rate for Gross domestic product, Inflation Rate and Exchanging Rate of the Islamic banking, also this study found significant and positive relationship between Return on Equity and Log TA, TL/ TA, TI/ TA and EPS of the Islamic banking, and there are significant and negative relationship between ROE and PRFCI/CF, TE / TA, GDPGR and INE of the Islamic banking".

Ahmed and Noor (2010, cited in Khan et al, 2015, p.78) conducted a study to examine the profitability and efficiency of Islamic banks. The results revealed that the banks with high profits are those with the higher operating expenses compared to assets and "more equity against assets and concentrated at high income countries demonstrating close relationship between monetary factors in determining Islamic banks profitability". 
Yusof et al. (2008, cited in Khan et al., 2015, p.78) "have regressed the relationship between the monetary policy and Islamic banks deposits of Bahrain and Malaysia for a period from 2001 to 2006. Regression model showed that Bahrain Islamic banks are opened to have influence of monetary policy while Malaysia Islamic banks are least.

\section{Methodology}

\subsection{Sample of Study}

Bahrain is a country that actively promotes Islamic finance worldwide by constantly producing and updating products and services based on sharia. The growth of Islamic financial institutions in the Middle East has become a rare case where Bahrain is among the global leaders (Central Bank of Bahrain, 2011, cited in (Zolkifi et al., 2015, p. 99). It has indicated in the literature that "Islamic banking has become a world community, particularly people in Asia who believe that rapid development has made famous Islamic banking worldwide" (Zolkifi et al., 2015, p. 99).

The study used six Islamic banks that have been in operation in Bahrain on or before 2010 until date. All Islamic banks in Bahrain have chosen to the study conditioning that they have been established on 2010 or before and their annual reports are available in these periods.

The following table presents list of banks in Bahrain.

Table 1. List of Islamic banks in Bahrain

\begin{tabular}{ll}
\hline The bank name \\
\hline 1. & Al Salam Bank \\
2. & Bahrain Islamic Bank \\
3. & Ithmaar Bank \\
4. & Albaraka Banking Group \\
5. & Khaleeji Commercial Bank \\
6. & Kuwait Finance Bank \\
\hline
\end{tabular}

\subsection{Data Collection}

Since the financial performance of the Islamic banks is evaluated on the basis of profitability and liquidity, the data has been compiled from the annual reports of the respective Islamic banks for the period of six years from 2010-2015 in Bahrain. The study used the secondary data, which has collected from published annual financial statements and reports of Islamic banks in Bahrain, internet, books and articles published in journals, and thus, the data for this study has collected from the annual financial statements and reports for each bank in Bahrain from websites.

\subsection{Study Tools}

Ratio analyze method was adopted in the current study. Using this method was justified because it was quite common used in the literature, example, Sabi (1996), Samad (1999) used financial ratios for evaluating performance of the banks.

\subsection{Model of the Study}

The model used in this study is based on time series cross-sectional bank level data in Bahrain. The model consists the following variables: 4 liquidity variables and 3 profitability variables.

Multiple regression analysis is used in the study to test the impact of liquidity on profitability. The variables used in the study are:

\section{- Dependent variables:}

1. Return on assets $(\mathrm{ROA})=$ Net income after taxes $/$ Total assets

2. Return on Equity $(\mathrm{ROE})=$ Net income after taxes $/$ Total equity

3. Return on deposits $(\mathrm{ROD})=$ Net income after taxes $/$ Total deposits

\section{- Independent variables:}

1. Cash \& due from banks to total assets $(\mathrm{CDTA})=$ cash and due from banks $/$ Total assets 
2. Cash \& due from banks to total deposits $($ CDTD $)=$ cash and due from banks / Total deposit

3. Investment (loans and advances) to total assets (INVESTA) $=$ Investment $/$ total assets

4. Investment (loans and advances) to total deposits (INVESTD) $=$ Investment $/$ total deposits

4.5 Development of Research Hypotheses

In the light of theoretical framework and literature review, the following hypotheses were developed:

H1: There is a significant relationship between liquidity and profitability (ROA) of Islamic banks in Bahrain.

$\mathrm{H} 2$ : There is a significant relationship between liquidity and profitability (ROE) of Islamic banks in Bahrain.

H3: There is a significant relationship between liquidity and profitability (ROD) of Islamic banks in Bahrain.

In the literature review many researchers used regression models include Demirgŭç- Kurt and Huizinga (1999), Haron (2004), Athanasoglou et al. (2008), Toni (2008), Naceur and Goaied (2008), Saleem and Rehman (2011), Khrawish et al. (2011) and Shahchera (2012). Thus, the current researcher used multiple regression models to test the hypotheses of the study. The models adopted are:

$$
\begin{aligned}
& \operatorname{ROA}_{i, t}=\alpha+\beta 1 \operatorname{CDTA}_{i, t}+\beta 2 \operatorname{CDTD}_{\mathrm{i}, \mathrm{t}}+\beta 3 \operatorname{INVSTA}_{\mathrm{i}, \mathrm{t}}+\beta 4 \operatorname{INVESTD}_{\mathrm{i}, \mathrm{t}}+€ \\
& \operatorname{ROE}_{\mathrm{i}, \mathrm{t}}=\alpha+\beta 1 \mathrm{CDTA}_{\mathrm{i}, \mathrm{t}}+\beta 2 \operatorname{CDTD}_{\mathrm{i}, \mathrm{t}}+\beta 3 \operatorname{INVESTA}_{\mathrm{i}, \mathrm{t}}+\beta 4 \operatorname{INVESTD}_{\mathrm{i}, \mathrm{t}}+€ \\
& \operatorname{ROD}_{\mathrm{i}, \mathrm{t}}=\alpha+\beta 1 \mathrm{CDTA}_{\mathrm{i}, \mathrm{t}}+\beta 2 \mathrm{CDTD}_{\mathrm{i}, \mathrm{t}}+\beta 3 \operatorname{INVESTA}_{\mathrm{i}, \mathrm{t}}+\beta 4 \operatorname{INVESTD}_{\mathrm{i}, \mathrm{t}}+€
\end{aligned}
$$

Where:

- $\quad$ ROA $=$ Return on assets

- $\quad$ ROE $=$ Return on Equity

- $\quad$ ROD = Return on deposits

- $\quad$ CDTA = cash and due from banks to total assets

- $\quad$ CDTD = cash and due from banks to total deposits

- $\quad$ INVESTA = investment (Loan \& advances) to total assets

- $\quad$ INVESTD = investment (Loan \& advances) to total deposits

- $\alpha=$ constant term.

- $\quad \beta=$ slopes associated with the independent variables, (liquidity)

- $\quad \mathrm{i}=$ Banks

- $\quad t=$ time

- $€=$ Error term

Four types of ratios are included in the current study as follows:

- Profitability ratios: It measures the managerial efficiency. Samad and Hassan (1999) used three profitability ratios to evaluate the performance of Islamic banks. The ratios used in the current study are:

- $\quad$ Return on Assets = Profit after tax / Total assets

- $\quad$ Return on Equity = Profit after tax / Total equity

- $\quad$ Return on deposits = Profit after tax / Total deposits

- Liquidity ratios: It measures the ability of the bank to pay its current obligations. Several measures of liquidity adopted in the literature. Samad and Hassan (1999) used two liquidity ratios, i.e., Loan/deposit ratio and current ratio. Hassan and Bashir (2003) also used the Net loans/total asset ratio as a measure of liquidity.

The ratios used in the current study are as follows:

- Cash and due from banks to total assets (CDTA)

- Cash and due from banks to total deposits (CDTD)

- Investment (Loan \& advances) to total assets) (INVSTA)

- $\quad$ Investment (Loan \& advances) to total deposits) (INVESTD) 


\section{Statistical Analysis and Results}

The analysis in this research includes the following:

\subsection{Descriptive Statistics}

Descriptive analyses are used to analyze the variables of the study. Table 2 below presents the descriptive analysis of Islamic banks in Bahrain. The results in the table indicate that minimum values of ROA and ROD, and to some extent in ROE leading to a high decrease in percentage of return for overall Islamic banking industry in Bahrain. The mean value of dependent variables means that the maximum percentage of bank's income belongs to shareholders, which implies higher outcome in comparison to ROA or ROD.

Table 2. Descriptive analysis

\begin{tabular}{lllll}
\hline & Minimum & Maximum & Mean & $\begin{array}{l}\text { Std. } \\
\text { Deviation }\end{array}$ \\
\hline Dependent variables & & & & \\
\hline ROE & -161.21 & 35.81 & 14.5206 & 25.514498 \\
\hline ROD & -4.32 & 2.73 & 1.0531 & 1.07421 \\
\hline ROA & -4.53 & 3.19 & 1.282 & 1071 \\
\hline Independent Variables & & & & \\
\hline CDTA & 7.77 & 64.19 & 16.7521 & 9.8460 \\
\hline CDTD & 10.33 & 84.83 & 22.5548 & 12.5046 \\
\hline INVSTA & 11.22 & 59.45 & 59.1069 & 9.6396 \\
\hline INVESTD & 12.27 & 82.27 & 66.76 & 12.3209 \\
\hline
\end{tabular}

\subsection{Correlation Coefficient}

Table 3 below presents the correlation coefficient analysis between all the dependent variables (profitability) and independent variables (liquidity) employed in the study. A Pearson correlation coefficients test is used in the analysis. The results of the study revealed that liquidity variables INVSTA and INVESTD positively related to all three liquidity variables. However, liquidity variables of CDTA and CDTD are negatively related with all selected profitability variables.

Table 3. Correlation coefficient analysis of profitability and liquidity variables

\begin{tabular}{|c|c|c|c|c|c|c|c|}
\hline & ROA & ROE & ROD & CDTA & CDTD & NVSTA & INVESTD \\
\hline ROA & 1 & & & & & & \\
\hline ROE & $.853 * *$ & 1 & & & & & \\
\hline ROD & $.891 * *$ & $.766^{* *}$ & 1 & & & & \\
\hline CDTA & -.198 & -.047 & -.216 & 1 & & & \\
\hline CDTD & -.199 & -.036 & -.201 & $.878 * *$ & 1 & & \\
\hline INVSTA & .210 & .025 & .211 & $-.855^{* *}$ & $-.872 * *$ & 1 & \\
\hline INVESTD & $.297 *$ & .096 & $.348 * *$ & $-.835^{* *}$ & $-.827 * *$ & $.911 * *$ & 1 \\
\hline \multicolumn{8}{|c|}{$\begin{array}{l}\text { Pearson Correlation Coefficient } \\
* * \text { Correlation is significant at the } 0.01 \text { level (2-tailed) }\end{array}$} \\
\hline
\end{tabular}

Source: Values calculated using annual reports of listed Islamic banks in Bahrain (2010-2015) 


\subsection{Regression Analysis}

Table 4 below presents the results of regression analysis. Four independent variables were regressed by using the data collected from the annual financial reports of Listed Islamic banks in Bahrain for the time series of $2010-2015$. The results in the table show that the adjusted value of $\mathrm{R}$ squares reveal that ROA is $16.2 \%$ dependent on independent variables (CDTA, CDTD, NVSTA, and INVESTD. As such, these liquidity variables strongly affect profitability of Islamic banks in Bahrain over the periods of study. The results in the table also show that CDTA, and INVSTD are correlated positively with ROA. On the other hand, CDTD and INVSTA show negative association with ROA. All independent variables CDTD, INVSTA and INVESTD except CDTA, are significantly correlated to ROA at 10\%, 1\% significant level respectively. Durbin-Watson test shows that the residuals are positively correlated. At overall, $1 \%$ significant level as per P-value the liquidity model (Model 1) is significantly correlated with ROA. Thus, the null hypothesis (H0) is rejected and the alternative hypothesis is accepted for the ROE.

Table 4. Regression results of ROA variable (2010-2015)

\begin{tabular}{|c|c|c|c|c|c|c|}
\hline \multirow[t]{2}{*}{ Model 1} & \multicolumn{3}{|c|}{ Unstandardized Coefficients } & \multirow{2}{*}{$\begin{array}{l}\text { Standardized Coefficients } \\
\text { Beta }\end{array}$} & \multirow[b]{2}{*}{$\mathrm{t}$} & \multirow[b]{2}{*}{ Sig. } \\
\hline & B & & Std. Error & & & \\
\hline Constant & 2.01 & & 2.949 & \multirow{5}{*}{$\begin{array}{l}3.371 \\
-3.532 \\
-1.881 \\
2.033\end{array}$} & .6441 & .471 \\
\hline CDTA & .282 & & .179 & & 1.517 & .116 \\
\hline CDTD & -.265 & & .156 & & -1.643 & $.092 *$ \\
\hline INVSTA & -.173 & & .065 & & -2.345 & $.009 * *$ \\
\hline INVESTD & .138 & & .047 & & 2.558 & $.004 * * *$ \\
\hline R squared & & .221 & F statistics & 3.596 & Durbin & 1.550 \\
\hline Adjusted R & uared & .162 & P-value & $.008 * * *$ & & \\
\hline
\end{tabular}

The results in the table below 5 show that the adjusted value of $\mathrm{R}$ squares reveal that ROE is $3.1 \%$ dependent on independent variables (CDTA, CDTD, NVSTA, and INVESTD. The results in the table also show that CDTD and INVESTD are correlated positively with ROE. In addition, CDTD, NVSTA indicate a negative correlation with ROE. Thus, only INVSTA and INVESTD found to be significant with ROE at 0.05 significant level. Durbin-Watson test shows that the residuals are uncorrelated since its value is approximately very close to 2 . However, according to the P-value, the overall liquidity model (Model 2) is not significantly related with ROE. Thus, the null hypothesis (H0) is accepted and the alternative hypothesis is rejected for the ROE.

Table 5. Regression results of ROE variable (2010-2015)

\begin{tabular}{|c|c|c|c|c|c|}
\hline \multirow[t]{2}{*}{ Mode 2} & \multicolumn{2}{|c|}{ Unstandardized Coefficients } & \multirow{2}{*}{$\begin{array}{l}\text { Standardized Coefficients } \\
\text { Beta }\end{array}$} & \multirow[b]{2}{*}{$\mathrm{t}$} & \multirow[b]{2}{*}{ Sig. } \\
\hline & B & Std. Error & & & \\
\hline Constant & 72.733 & 82.449 & \multirow{5}{*}{$\begin{array}{l}2.823 \\
-2.695 \\
-1.459 \\
1.672\end{array}$} & .823 & .356 \\
\hline CDTA & 6.245 & 4.498 & & 1.183 & .145 \\
\hline CDTD & -5.340 & 3.507 & & -1.168 & .103 \\
\hline INVSTA & -3.551 & 1.552 & & -1.694 & $.019 * *$ \\
\hline INVESTD & 2.996 & 1.311 & & 1.960 & $.023 * *$ \\
\hline R squared & .082 & F statistics & 1.157 & n-Waston & 1.431 \\
\hline Adjusted R squared & .031 & P-value & .124 & & \\
\hline
\end{tabular}

The results in the table 6 show that the adjusted value of R squares reveal that ROE $2.13 \%$ dependent on independent variables (CDTA, CDTD, NVSTA, and INVESTD. The results in the table show that CDTA and INVESTD are positively correlated with ROD, and negatively with CDTA and INVSTA, and CDTA is the only insignificant 
variable. CDTD is significantly related with ROD at $10 \%$. Durbin-Watson test shows that the residuals are positive auto - correlated since its value is approximately very close to 1 . However, according to the P-value, the overall liquidity model (Model 3), is significantly related with ROD at 1\% level. Thus, the null hypothesis (H0) is rejected and the alternative hypothesis is accepted for the ROD.

Table 6. Regression results of ROD variable (2010-2015)

\begin{tabular}{|c|c|c|c|c|c|c|c|}
\hline \multirow[t]{2}{*}{ Mode 3} & \multicolumn{3}{|c|}{ Unstandardized Coefficients } & \multirow{2}{*}{\multicolumn{2}{|c|}{$\begin{array}{l}\text { Standardized Coefficients } \\
\text { Beta }\end{array}$}} & \multirow[b]{2}{*}{$\mathrm{t}$} & \multirow[b]{2}{*}{ Sig. } \\
\hline & $\mathrm{B}$ & & Std. Error & & & & \\
\hline Constant & 2.110 & & 3.004 & \multirow{5}{*}{$\begin{array}{l}3.193 \\
-3.367 \\
-.1995 \\
2.392\end{array}$} & & .608 & .421 \\
\hline CDTA & .312 & & .189 & & & 1.506 & .098 \\
\hline CDTD & -.294 & & .166 & & & $\begin{array}{l}-1.642 \\
\end{array}$ & .076 \\
\hline INVSTA & -.214 & & .071 & & & -2.607 & .003 \\
\hline INVESTD & .189 & & .056 & & & 3.155 & .000 \\
\hline \multicolumn{2}{|l|}{ R squared } & .262 & F statistics & 4.686 & Durbi & aston & 1.386 \\
\hline \multicolumn{2}{|c|}{ Adjusted R squared } & .213 & P-value & .000 & & & \\
\hline \multicolumn{8}{|c|}{$* * *$ Significant at the $1 \%$ level } \\
\hline \multicolumn{8}{|c|}{$* *$ Significant at the $5 \%$ level } \\
\hline \multicolumn{4}{|c|}{ * Significant at the $10 \%$ level } & & & & \\
\hline
\end{tabular}

Source: Values calculated using annual reports of listed Islamic banks in Bahrain (2010-2015)

\section{Conclusions and Recommendations}

The major conclusion of this study is that liquidity strongly affects profitability of Islamic banks in Bahrain over the periods of study. In other words; profitability of Islamic banks depends to a large extent upon liquidity. More specifically, the study concluded that the liquidity variable CDTA is insignificant with any of the profitability variables, whereas, the liquidity variable CDTA is found to be significant with the profitability variables ROA and ROD at $10 \%$ level and insignificant with ROE. Regarding the variable INVSTA and the variable INVESTD both are significantly correlated with all selected profitability variables. The CDTA is significant with ROA and ROD at $1 \%$ level and with ROE at 5\% level. On the other hand, CDTA is significantly correlated with ROA and ROD at $1 \%$ level and with ROE at 5\% level. The overall liquidity model was found significant with ROA and ROD at $1 \%$ level and not significant with ROE. The results of the study show that CDTD and INVESTD are correlated positively with ROE. In addition, CDTD, NVSTA indicate a negative correlation with ROE. Thus, only INVSTA and INVESTD found to be significant with ROE at 0.05 significant levels. Durbin-Watson test shows that the residuals are uncorrelated since its value is approximately very close to 2

It is important to note that Islamic bank keeping high liquidity has both merits and drawbacks. There is no need to keep excess liquidity, (instead the amount can be invested profitably) and whenever need arises JIS (Just-In-System) model be used to meet the customers demand for cash (Suresh and Bardastani, 2016, p. 54). Therefore, without maintaining proper liquidation balance (neither too high nor too low) Islamic banks cannot reach their target profits.

The current study serves as initial movement in Bahrain, leaving spaces for future studies, adding more liquidity variables to the model in order to enhance and enrich outlook. In addition, it should be noted that liquidity is not the only reason that affect profitability in Bahraini Islamic banks, and therefore, Islamic Banks need critically to review their cost structure and measures taken to control it (Suresh and Bardastani, 2016, p. 54).

This research has been conducted, only by getting five years data of a popular commercial bank (Habib Bank Limited) in Pakistan. Hence it cannot be generalized to other smaller sized banks like DFIs. Moreover, to make the findings more generalizable, the sample size can be increased and the numbers of years for data collection may also be increased. Moreover to make the study more reliable, data of some other leading Islamic banks in the region can also be brought to analysis, so that the findings will be more reliable. 


\section{References}

Abdul-Majid, M., Saal, D. S., \& Battisti, G. (2011). The impact of Islamic banking on the cost efficiency and productivity change of Malaysian commercial banks. Applied Economics, 43(16), 2033-2054. https://doi.org/10.1080/00036840902984381

Ahmad, H. N., \& Noor, M. A. N. M. (2010). The determinants efficiency and profitability of World Islamic banks. International Conference on E-business, Management and economics IPEDR.

Akhter, W., Raza, A., Orangzab, \& Akram, M. (2011, February). Efficiency and performance of Islamic Banking: The case of Pakistan. Far East Journal of Psychology and Business, 2(2), 54-70. Retrieved from http:/www.fareastjournals.com/files/V2N2P4.pdf.01/05/2012

Ariff, M. (1988). Islamic Banking. Asian - Pacific Economic Literature, $2(2)$, 46-62. https://doi.org/10.1111/j.1467-8411.1988.tb00200.x

Babatunde, O. A., \& Olaitan, O. A. (2013, February). The performance of conventional and Islamic banks in the United Kingdom: A comparative Analysis. Journal of research in Economics and International finance (JRELF), 2(2), 29-38.

Ben Khediria, K., Charfeddined, L., \& Slah, B. Y. (2015). Islamic versus conventional banks in the GCC countries, A comparative study using classification techniques. Research in International Business and Finance, 33, 75-98. https://doi.org/10.1016/j.ribaf.2014.07.002

Chapra, M. U. (1996). What is Islamic economics. Islamic Development Bank Jeddah in IDB Prize Winner's Lecture Series No. 9 (1st ed.). IRTI.

Demerguc-Kunt, A., \& Huizinga, H. (1999, May). Determinants of commercial bank interest margins and profitability: Some international evidence. World Bank Economic Review, 13(2), 379-408. https://doi.org/10.1093/wber/13.2.379

EL, G., \& Zeinab, M. (2005). Possibility of cooperation between Islamic banks and conventional banks. Misr University for Science and Technology, $6^{\text {th }}$ October University. Retrieved from http://www.must.edu.eg/Publications/Business_Res4.pdf

El-Gamal, M. A., \& Inanoglu, H. (2005). Inefficiency and Heterogeneity in Turkish banking: 1990-2000. Journal of Applied Econometrics, 20, 641-669. https://doi.org/10.1002/jae.835

Ernst, \& Young. (2012). World Islamic banking competitiveness Report 2013 growing beyond DNA of successful transformation. Retrieved from http://www.mifc.com/index.php?ch=151\&pg=735\&ac=818\&bb=file 1

Haron, S. (2004). Determinants of Islamic bank profitability. The Global Journal of Finance and Economics, 1(1), $2-18$.

Haron, S., \& Shanmugan, B. (1997). Islamic banking system- concepts and Applications, pp.35-42. Malaysia: Planduk Publications.

Hassan, M. K., \& Bashir, A. H. M. (2003). Determinants of Islamic banking profitability in the ERF. Journal Conference, 16, 1-31.

HM Treasury. (2007). Economic secretary speech, London Islamic Financial Services Summit, London. Retrieved from www.hm- treasury.gov.uk./newsroom_and_speeches/speeches/econsecspeeches/speech_est_290307.cfm

Ibrahim, M. A. (2014). A comparative performance of two banks in United Arab Emirates. Research Journal of Finance and Accounting, 5(21), 24-29.

Ika, S. R., \& Abdulla, N. (2011, August). A comparative study of financial performance of Islamic banks and conventional banks in Indonesia. International Journal of business and Social Science, 2(15), 199-207. Retrieved from http://www.ijbssnet.com/journals/Vol_2_No_15_August_2011/22.pdf.12/8/2012

Islam, M. M. (2008, November). Liquidity management. Text Book on Islamic Banking (2 ${ }^{\text {nd }}$ ed.), pp.101-111. Dhaka (Bangladesh): Islamic economics Research Bureau.

Islam, M., \& Salim, M. (2011, July). Analysis of the operational efficiency of commercial banks: A study of the Islamic banks in Bangladesh. Journal of Banking and Financial Services, 5(1), 83-96. 
Islam, M., Alam, I., \& Hossain. Sk. (2014). Examination of profitability between Islamic banks and conventional banks in Bangladesh: A comparative study. Research in Business and Management, 1(1), 78-89. https://doi.org/10.5296/rbm.v1i1.4894

Jill, J., Marwan, I., \& Vasilleios, P. (2009). The efficiency of Islamic and conventional banks in the Gulf Cooperation Council (GCC) countries: An analysis using financial ratios and data equipment analysis. Working Paper. Lancaster University Management School, Lancaster. Retrieved from http://eprints.lancs.ac.uk/48965/1/document.pdf

Khan, M. A., Ali, M., \& Khan, M. A. (2015). Examine Gauging profitability and liquidity of Islamic banks: Evidence from Malaysia and Pakistan. International Journal of Accounting and Financial Reporting, 5(1), 75-90. https://doi.org/10.5296/ijafr.v5i1.6865

Khrawish, H. A., Siam, W. Z., \& Khrawish, A. H. (2011, May). Determinants of Islamic bank profitability: Evidence from Jordan. Middle Eastern Finance and Economics, 3, 43-57.

Milhem, M. M., \& Istaiteyeh, R. M. S. (2015). Financial performance of Islamic and conventional banks: Evidence from Jordan. Global Journal of Business Research, 9(3), 27-41.

Naceur, S. B., \& Goaied, M. (2008). The determinants of commercial bank interest margin and profitability: Evidence from Tunisia. Frontiers in Finance and Economics, 5(1), 106-130.

Najjar, N. J. (2013). Can financial ratios reliably measure the performance of banks in Bahrain. International Journal of Economics and Finance, 5(3), 152-163. https://doi.org/10.5539/ijef.v5n3p152

Paul, S. C., Bhowmik, P. K., Islam, M. R., Karisal, Hd. A., \& Masud A. Al. (2013). Profitability and liquidity of conventional banking and Islamic banking in Bangladesh. European Journal of Business and Management, 5(24), 113-123.

Rajesh, K., Aggarwal, \& Yousef, T. (2000). Islamic banks and investment. Journal of Money, Credit and Banking, 32(1), 93-120. https://doi.org/10.2307/2601094

Rana, M., Hossain, Md. K., \& Rekha, R. S. (2016). Profitability and liquidity of conventional banking and Islamic Banking in Bangladesh: A comparative study. International Journal of Applied Research, 2(9), 318-327.

Rana, M., Hossain, Md. K., \& Rekha, R. S. (2016). Profitability and liquidity of conventional banking and Islamic Banking in Bangladesh: A comparative study. The State Bank of Pakistan (SBP). Retrieved from http://www.thenews.com.pk/.../149822-SBP-exempt-islamic-banks.from-using-inter

Rasul, L. M. (2013). Impact of liquidity on Islamic Bank profitability: Evidence from Bangladesh, 2013, ACTA University. DANUBIUS, 9(2), 23-36

Rose, P. S. (2004-2005). Commercial Bank Management, pp.149-198. U.S.A: Irwin / McGraw-Hill Companies.

Rosly, S. A., \& Bakar, M. A. A. (2003). Performance of Islamic mainstream banks in Malaysia. International Journal of Social Economics, 30(12), 1249-1265. https://doi.org/10.1108/03068290310500652

Ryu, K. P., Piao, S. Z., \& Nami, D. (2012). A comparative study between the Islamic and conventional banking systems and its implications. Scholarly J. Bus. Admin., 2(5), 48-54.

Sabi, M. (1996). Comparative analysis of foreign and domestic bank operation in Hungary. Journal of Comparative Economics, 22, 179-188. https://doi.org/10.1006/jcec.1996.0017

Saleem, Q., \& Reham, R. Ur. (2011, July). Impacts of liquidity ratios on profitability (Case of oil and gas companies of Pakistan. Interdisciplinary Journal of Research in Business, 1(7), 95-98. Retrieved March 8, 2012, from http://www.idjrb.com/articlepdf/idjrb7n9.pdf

Samad, A. (1999). Comparative efficiency of the Islamic bank Malaysia vis-à-vis conventional banks. Journal of Economics and Management, 7(1), 112-126.

Samad, A. (2004). Performance of interest-free Islamic banks VIS-À-VIS interest based conventional Banks of Bahrain. IIUM Journal of Economics and Management, 12(2), 1-15.

Samad, A., \& Hassan, M. K. (1999). The performance of Malaysian Islamic bank during 1984-1997: An explanatory study. International Journal of Islamic Financial Services, 1(3).

Shahchera, M. (2012). The impact of liquidity asset on Iranian bank Profitability. International Conference on Management, Behavioral Science and Economics Issues (ICMBSE'2012), pp.131-135. Penang, Malaysia. 
Suresh, C., \& Bardastani, M. (2016, May). Financial performance of selected conventional and Islamic banks in Kingdom of Bahrain - A CAMEL ranking based approach. European Journal of contemporary Economics and Management, 3(1), 23-59.

Toni, U. (2008). Determinates of bank profitability: Macroeconomic Evidence from Nigeria. Working paper, Deakin University.

Usman, A., \& Khan, M. K. (2012, April). Evaluating the financial performance of Islamic and conventional banks of Pakistan. A comparative analysis. International Journal of Business and Social Science, 3(7), 253-257.

Yudistira, D. (2003). Efficiency of Islamic banks: An empirical analysis of 18 banks. United Kingdom: Leicestershire Le11 3TU.

Yusof, M. R., Wosabi, M. A., \& Majid, M. S. A. (2008). $8^{\text {th }}$ Global Conference on business and economics, monetary policy shocks and Islamic banks' deposits in a Dual banking system: A comparative analysis between Malaysia and Bahrain. Florence, Italy.

Zolkifli, N., Hamid, M. A., \& Janor, H. (2015). Liquidity risk and performance: The case of Bahrain and Malaysian banks. Global Economy and Finance Journal, 8(2), 95-111. https://doi.org/10.21102/gefj.2015.09.82.07 